\title{
Origin of Leukemic Relapse After Bone Marrow Transplantation Detected by Restriction Fragment Length Polymorphism
}

\author{
M. D. Minden, H. A. Messner, and A. Belch \\ Ontario Cancer Institute, Toronto, Ontario M4X 1K9, Canada, and Cross Cancer Institute, Edmonton, Alberta T6G 1Z2, Canada
}

\begin{abstract}
Bone marrow transplantation has become an accepted modality in the treatment of acute leukemia. With this therapy, it is possible to obtain long-term disease-free survival. However, leukemia recurs occasionally. In most cases, leukemic relapse is of recipient origin. There have been several reports, though, of leukemia developing in donor cells. These cases have been limited to instances in which there is an easily identifiable chromosome difference or abnormality, usually a sex chromosome. In this paper we describe the use of restriction fragmentlength polymorphism analysis to determine the origin of recurrent leukemia cells in which no identifying chromosome was present. We found that the leukemia had recurred in recipient cells. We also were able to demonstrate the presence of normal hemopoietic cells of donor origin.
\end{abstract}

\section{Introduction}

Bone marrow transplantation has become an accepted part of the treatment of acute leukemia (1). Although there are many disease-free long-term survivors, leukemia recurs occasionally. In most cases, recurrent leukemic cells are of recipient origin. However, there have been reports of leukemia or lymphoma developing in donors' cells (2-9). In general, these reports have been limited to transplants in which there has been a sex mismatch, and therefore an easily identifiable chromosome difference.

A method that would permit the study of the origin of hemopoietic cells from most, if not all, patients undergoing bone marrow transplantation would be desirable. This requires a more general technique than chromosome analysis. The method of restriction fragment length polymorphisms (RFLP) has this characteristic. Shubach et al. (8) have used this technique to demonstrate the donor origin of lymphoma cells in a patient after bone marrow transplantation.

Certain cloned pieces of DNA, when hybridized to human DNA that has been cut with a restriction enzyme and separated by electrophoresis, recognize fragments of varying length in different individuals. This variation in fragment length, detected

Address correspondence to Dr. Minden, Ontario Cancer Institute, 500 Sherbourne St., Toronto, Ontario M4X 1K9, Canada.

Dr. Minden is a scholar of the Leukemia Society of America.

Received for publication 17 May 1984 and in revised form 27 August 1984.

1. Abbreviations used in this paper: RFLP, restriction fragment length polymorphisms; SSC, sodium chloride sodium citrate.

J. Clin. Invest.

(c) The American Society for Clinical Investigation, Inc.

0021-9738/85/01/0091/03 $\$ \$ 1.00$

Volume 75, January 1985, 91-93 by a unique cloned piece of DNA, is referred to as RFLP. Population and family studies indicate that these variations of DNA fragment length are inherited in a Mendelian fashion with one allele coming from the mother and the other allele coming from the father. The concept and use of RFLP has been reviewed by Botstein et al. (10). In this paper, we describe the use of RFLP to determine the origin of leukemic blasts and normal cells in a patient after transplantation.

\section{Methods}

The patient was a 20-yr-old male with acute myeloblastic leukemia. At the time of bone marrow transplantation, he was in a second complete remission. The donor was the patient's younger brother. The donor's hematological values were normal at the time of transplantation. The patient was treated with $100 \mathrm{mg} / \mathrm{m}^{2}$ Ara-C for $5 \mathrm{~d}$ by continuous infusion followed by $60 \mathrm{mg} / \mathrm{kg}$ cyclophosphamide on two consecutive days. $2 \mathrm{~d}$ after cyclophosphamide, the patient received $500 \mathrm{rad}$ total body irradiation followed immediately by infusion of donor bone marrow cells. The posttransplantation period was uneventful and on the 14th day the granulocyte count was $>10^{3} / \mathrm{mm}^{3}$. 2 mo after transplantation, the patient was discharged with normal hematological values. He was well for the next $6 \mathrm{mo}$, when a routine hematology examination revealed the presence of blasts in the peripheral blood. When blood was obtained for the studies described in this paper, the leukocyte count was $14,000 / \mathrm{mm}^{3}$, with $70 \%$ blasts, $10 \%$ granulocytes, and $20 \%$ lymphocytes. Attempts at inducing remission were unsuccessful and the patient died $\sim 2$ mo after relapse.

Sources of DNA. DNA was obtained from the peripheral blood cells of the donor and the recipient. Mononuclear cells were separated by Ficoll-Hypaque centrifugation (11). A fraction of cells enriched for granulocytes was prepared by lysing the erythrocytes in the pellet. Populations of cells enriched and depleted for $T$ lymphocytes were obtained by $\mathrm{E}$ rosette depletion of the mononuclear cell fraction (12). The purity of the fractions was assessed by morphology of Wright stained cells.

Skin fibroblast cells were recovered from a fresh skin biopsy.

Preparation of DNA. Cells were washed in phosphate-buffered saline and then resuspended in $10 \mathrm{mM}$ Tris, $100 \mathrm{mM} \mathrm{NaCl}, 1 \mathrm{mM}$ EDTA, pH 7.4. The cell suspension was added to an equal volume of $10 \mathrm{mM}$ Tris, $100 \mathrm{mM} \mathrm{NaCl}, 1 \mathrm{mM}$ EDTA, pH 7.4, containing 400 $\mu \mathrm{g} / \mathrm{ml}$ of proteinase $\mathrm{K}$ and $1 \%$ sodium dodecyl sulfate. This suspension was incubated at $37^{\circ} \mathrm{C}$ overnight. The suspension was then extracted once with phenol chloroform isoamyl alcohol 25:24:1 and twice with chloroform isoamyl alcohol 24:1. The DNA was precipitated with isopropyl alcohol and resuspended in $10 \mathrm{mM}$ Tris, $1 \mathrm{mM}$ EDTA, pH 7.4.

Southern blot analysis. DNA was cut with the restriction enzyme Eco R1 and separated on a $0.8 \%$ agarose gel at $2 \mathrm{~V} / \mathrm{cm}$ for $2 \mathrm{~d}$. The DNA was transferred to nitrocellulose paper and the filter was baked at $80^{\circ} \mathrm{C}$ in a vacuum for $2 \mathrm{~h}$ (13). The filter was prehybridized in hybridization buffer consisting of six times sodium chloride sodium citrate (SSC) (one times SSC is $0.15 \mathrm{M} \mathrm{NaCl}, 0.015 \mathrm{M} \mathrm{Na}$ citrate), $0.1 \%$ pyrophosphate, $0.1 \%$ sodium dodecyl sulfate, $200 \mu \mathrm{g} / \mathrm{ml}$ of salmon sperm DNA, and five times Denhardt's solution at $65^{\circ} \mathrm{C}$ overnight. ${ }^{32} \mathrm{P}$-labeled probe in hybridization buffer was added to the filter, and hybridization was carried out at $65^{\circ} \mathrm{C}$ for $24 \mathrm{~h}$. The filter 
was then washed in successive 30-min washes in two times SSC, one times SSC, and 0.1 times SSC. Washes were all done at $65^{\circ} \mathrm{C}$. The filter was then exposed to film (XAR-5; Eastman Kodak Co., Rochester, NY) with an intensifying screen at $-70^{\circ} \mathrm{C}$ for $24 \mathrm{~h}$.

Probe. The probe used in this study was pAW 101 (D14S1) (14). The clone was kindly provided by Dr. Ray White. The plasmid DNA was made radioactive by nick translation with ${ }^{32} \mathrm{P}$-alpha deoxycytidine triphosphate (15).

Cytogenetics. Metaphase spreads were prepared from bone marrow cells at the time of initial presentation and at the time of leukemic relapse after transplantation. Metaphase spreads from phytohemaglutinin-stimulated peripheral blood cells of the donor were also analyzed.

\section{Results}

The results of this study are depicted in Fig. 1. DNAs on the left side of the blot were from the recipient, while the DNA in the two right lanes was from the donor. By comparing the pattern of the recipient's fibroblasts and the donor's peripheral blood cells, it is evident that the donor and recipient display RFLP. DNA from the first Ficoll-Hypaque cells of the recipient yielded a mixed pattern, indicating the presence of both donor and recipient cells. Analysis of separated cells, however, revealed that the blast cells contain only DNA of the recipient type. The fractions enriched for $T$ cells and granulocytes contained DNA with a mixed donor and recipient pattern. However, the intensity of the donor band was greater. This suggests that in this population of cells from which this DNA was made, the majority of the cells were of donor type.

The purity of the fraction was assessed by light microscopy of Wright stained cells. The blast-cell population consisted of $>99 \%$ blasts. However, the granulocyte fraction and $\mathrm{E}$ rosette positive fraction contained $\sim 15 \%$ blast cells.

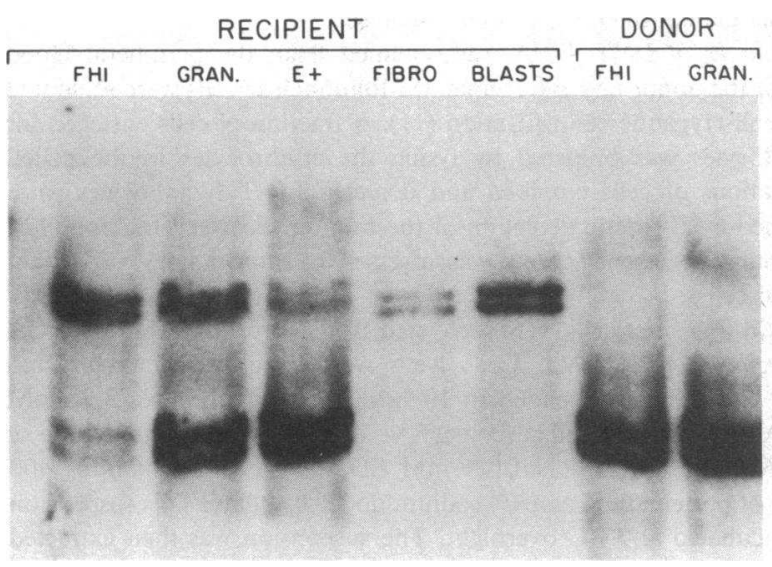

Figure 1. Restriction enzyme analysis of DNAs from the donor and recipient. DNAs were cut with the restriction enzyme Eco $R 1$, separated by electrophoresis on a $0.8 \%$ agarose gel, and transferred to nitrocellulose. The filter was probed with radioactively labeled pAW 101. The DNAs on the left side were obtained from the recipient, while the DNAs on the right side were obtained from the donor. The DNAs used were derived from the following cell types: FHI are mononuclear cells obtained from the Ficoll-Hypaque interface; gran. are the cells recovered from the pellet of the first Ficoll-Hypaque; E+ are the cells that formed sheep erythrocyte rosettes; fibro. are the fibroblasts obtained from a skin biopsy; and blasts are the peripheral blood mononuclear cells that have been depleted of $\mathrm{T}$ lymphocytes.
Chromosome analysis revealed that there were no cytogenetic polymorphisms between donor and recipient cells. Also, no karyotypic abnormalities were seen in the samples obtained at presentation or following relapse after bone marrow transplantation. Thus, using cytogenetics, it was not possible to differentiate donor from recipient cells, nor was it possible to determine whether the leukemic cells at relapse were members of the original leukemic clone.

\section{Discussion}

In this case, we used the analysis of a RFLP in the DNA of the donor and recipient to identify the origin of the leukemic blast cells and the coexisting normal cells in a patient after bone marrow transplantation. The leukemic cells in this case were found to be of recipient origin. Note, however, that fractions enriched for $\mathrm{T}$ lymphocytes and granulocytes contained cells of donor as well as recipient origin. This indicated that engraftment had occurred and donor cells of the granulocytic and lymphoid lineage were being produced. From this analysis, it is not possible to tell whether the bands of recipient origin in the granulocyte or E+ DNA samples were due to concomitant production of granulocytes and $\mathrm{T}$ cells by recipient cells, or contamination of the fractions by leukemic blast cells. The enrichment techniques used in this study are relatively inefficient; $\sim 15 \%$ of the granulocyte and $T$ cell-enriched fractions were blast cells. This level of contamination can be detected with the method we used to analyze the DNA. This problem may be avoided by using better separation techniques.

The technique of using RFLPs to identify the origin of cells in patients after bone marrow transplantation regardless of their sex should be useful in determining the origin of leukemic cells as was done in this study. The method should also permit kinetic studies of the growth of engrafted marrow (16). This approach may be refined by using cell-separation techniques to assess various lineages independent of each other. As this technique does not require cell proliferation, it can be used on cells that do not divide, such as granulocytes, or cells that are difficult to stimulate, such as B cells.

In the present case a polymorphic marker, recognized by pAW 101, on chromosome 14 was used (17). pAW 101 is highly polymorphic in the population and as such is very useful. However, as there is a $25 \%$ chance that two siblings will inherit the same pair of chromosome $14 \mathrm{~s}$, the maximum utility of any single highly polymorphic probe is $\sim 75 \%$ of cases. In theory, by using clones that recognize polymorphisms on other chromosomes (18), except for possibly chromosome 6, which carries the HLA genes (18), it should be possible to identify the origin of nucleated blood cells after bone marrow transplantation in all cases except where the donor and recipient are identical twins.

\section{Acknowledgments}

We would like to thank A. Bryden for typing this manuscript. This work was supported by the National Cancer Institute of Canada and the Medical Research Council of Canada.

\section{References}

1. Thomas, E. D. 1983. Bone marrow transplantation in leukemia. In Modern Trends in Human Leukemia, Vol. V. R. Neth, R. C. Gallo, 
M. F. Greaves, M. A. S. Moore, and K. Winkler, editors. SpringerVerlag, Berlin/Heidelberg/New York/Tokyo. 11-15.

2. Fialkow, P. J., E. D. Thomas, J. I. Bryant, and P. E. Neiman. 1971. Leukemic transformation of engrafted human marrow cells in vivo. Lancet. I:251-255.

3. Thomas, E. D., J. I. Bryant, C. D. Buckner, R. A. Clift, A. Fefer, F. L. Johnson, P. Neiman, R. E. Ramberg, and R. Storb. 1972. Leukemic transformation of engrafted human marrow cells in vivo. Lancet. I:1310-1313.

4. Goh, K., and M. R. Klempereer. 1977. In vivo leukemic transformation: cytogenetic evidence of in vivo leukemic transformation of engrafted marrow cells. Am. J. Hematol. 2:283-290.

5. Elfenbein, G. J., D. S. Brogaonkar, W. B. Bias, W. H. Burns, R. Sar, L. L. Sensenbrenner, P. J. Tutschka, B. S. Zaczek, A. R. Zand R. B. Epstein, J. D. Rowley, and G. W. Santos. 1978. Cytogenetic evidence for recurrence of acute myelogenous leukemia after allogeneic bone marrow transplantation in donor hematopoietic cells. Blood. 52:627-636.

6. Gossett, R. C., R. P. Gale, H. Fleischman, G. E. Austin, R. S. Sparks, and C. R. Taylor. 1979. Immunoblastic sarcoma in donor cells after bone marrow transplantation. N. Engl. J. Med. 300:904-907.

7. Newburger, P. E., S. A. Latt, J. M. Pesando, K. Gustashaw, M. Pows, R. S. K. Chaganti, and R. J. O'Reilley. 1981. Leukemia relapse in donor cells after allogeneic bone marrow transplantation. $N$. Engl. J. Med. 304:712-714.

8. Schubach, W. H., R. Hackman, P. E. Neiman, G. Miller, and E. D. Thomas. 1982. A monoclonal immunoblastic sarcoma in donor cells bearing Epstein-Barr virus genomes following allogeneic grafting for acute lymphoblastic leukemia. Blood. 60:180-187.
9. Boyd, C. N., R. C. Ramberg, and E. D. Thomas. 1982. The incidence of recurrence of leukemia in donor cells after allogeneic bone marrow transplantation. Leuk. Res. 6:833-837.

10. Botstein, D., R. L. White, M. Skolnick, and R. W. David. 1980. Construction of a genetic linkage map in man using restriction fragment length polymorphisms. Am. J. Hum. Genet. 32:314-331.

11. Boyum, A. 1968. Separation of leukocytes from blood and bone marrow. Scand. J. Lab. Invest. 21:1-8.

12. Minden, M. D., R. N. Buick, and E. A. McCulloch. 1979. Separation of blast cell and myeloblastic leukemia. Blood. 54:186-195.

13. Southern, E. M. 1975. Detection of specific sequences among DNA fragments separated by gel electrophoresis. J. Mol. Biol. 98:503517.

14. Wyman, A., and $R$. White. 1980. A highly polymorphic locus in human DNA. Proc. Natl. Acad. Sci. USA. 77:6754-6758.

15. Rigby, P. W. J., M. Diekman, C. Rhodes, and P. Berg. 1977. Labelling deoxyribonucleic acid to high specific activity in vitro by nick translation with DNA polymerase. J. Mol. Biol. 113:237-251.

16. Ginsburg, D., J. H. Antin, B. R. Smith, S. H. Orkin, and J. M. Rappeport. 1983. The use of DNA restriction enzyme polymorphisms to distinguish cells of host or donor origin following allogeneic bone marrow transplantation (BMT). Blood. 62:222a. (Abstr.)

17. De Martinville, B., A. R. Wyman, R. White, and U. Francke. 1982. Assignment of the first random restriction fragment length polymorphisms (RFLP) locus (D14S1) to a region of human chromosome. 14. Am. J. Hum. Genet. 34:216-226.

18. Skolnick, M. H., H. F. Willard, and L. A. Menlove. 1984 Report of the committee on human gene mapping by recombinant DNA techniques. Cytogen. Cell Genet. 37:210-273. 